\title{
Cancer Risk due to Radionuclides Concentration in Tin Ores and Sediments at Barkin-Ladi, Plateau State, North Central, Nigeria
}

\author{
Masok Felix Bitrus ${ }^{1,5}$, Ike-Ogbonna Margaret Igeoma ${ }^{2}$, Dawam Robert Rangmou², \\ Jwanbot Daniel Ibrahim $^{3}$, Yenle Nandi Michael ${ }^{4}$ \\ ${ }^{1}$ Department of Applied Physics and Engineering Mathematic, University of Johannesburg, Johannesburg, South Africa \\ ${ }^{2}$ Department of Remedial Sciences, University of Jos, Jos, Nigeria \\ ${ }^{3}$ Department of Physics, University of Jos, Jos, Nigeria \\ ${ }^{4}$ Department of Environmental Health, College of Health Technology, Zawan, Nigeria \\ ${ }^{5}$ Department of Physics, Plateau State University, Bokkos, Nigeria
}

Email address:

masokfelix@gmail.com (F. B. Masok),fmasok@uj.ac.za (F. B. Masok)

\section{To cite this article:}

Masok Felix Bitrus, Ike-Ogbonna Margaret Igeoma, Dawam Robert Rangmou, Jwanbot Daniel Ibrahim, Yenle Nandi Michael. Cancer Risk due to Radionuclides Concentration in Tin Ores and Sediments at Barkin-Ladi, Plateau State, North Central, Nigeria. International Journal of Environmental Monitoring and Analysis. Vol. 3, No. 5, 2015, pp. 260-264. doi: 10.11648/j.ijema.20150305.13

\begin{abstract}
The specific activity concentrations of natural radionuclides ${ }^{40} \mathrm{~K},{ }^{226} \mathrm{Ra}$ and ${ }^{232} \mathrm{Th}$ in soil samples of abandoned tin ore and sediment from tin mining areas at Barkin-ladi were measured by gamma-ray spectrometry system using Sodium Iodide [NaI(Tl)] detector. Radiological hazard assessments due to these natural radionuclides were carried out. The aim was to assess the associated lifetime cancer risk owing to inhalation of the short life Radon gas from the tin ore and sediments by the inhabitants of this area after 70 years of exposure. The calculated activity concentrations of ${ }^{40} \mathrm{~K},{ }^{226} \mathrm{Ra}$ and ${ }^{232} \mathrm{Th}$ in the collected ore samples were $275.44 \pm 46.14,239.95 \pm 30.82$ and $778.78 \pm 29.30 \mathrm{Bqkg}^{-1}$ respectively while those of the sediment samples were $1608.25 \pm 55.60,759.62 \pm 47.95$ and $4861.82 \pm 48.78 \mathrm{Bqkg}^{-1}$ respectively. However, the mean absorbed dose rate in ores $\left(629.86 \mathrm{nGyh}^{-1}\right)$ and in sediments $\left(3612.05 \mathrm{nGyh}^{-1}\right)$, the mean radium equivalent in ores $\left(1374 \mathrm{Bqkg}^{-1}\right)$ and in sediments $\left(7835.88 \mathrm{Bqkg}^{-1}\right)$ and the mean annual effective dose rate in ores $\left(0.77 \mathrm{mSvy}^{-1}\right)$ and in sediments $\left(4.43 \mathrm{mSvy}^{-1}\right)$ were all found to be higher than the recommended global average values of $59 \mathrm{nGy}^{-1}, 370 \mathrm{Bgkg}^{-1}$ and $0.07 \mathrm{mSvy}^{-1}$ correspondingly. The excess lifetime cancer risk (ELCR) value obtained in this study for the ores samples ranges from 0.0026 to 0.0473 with an average of 0.0107 while the ELCR value in sediments samples was found to range from 0.3205 to 0.0036 with an average of 0.0620 . Although the study reveals an average excess lifetime cancer risk value to be more in the sediment samples compare to ore samples, the excess lifetime cancer value within all the sample locations were above the world average value of 0.00029 . Therefore, the present study reveals a lifetime cancer risk to the general public within this study area thus precaution need to be taken by ensuring inhabitants live in well ventilated houses since no level of radioactivity is harmless.
\end{abstract}

Keywords: Specific Activities, Excess Lifetime Cancer, Tin Ore and Sediments, Annual Effective Dose

\section{Introduction}

The exposure of the entire livings creatures to terrestrial ionizing radiation is as old as the commencement of time. Many isotopes contribute to natural radiation and can be grouped into Terrestrial sources (coming from ground) or cosmogenic sources (coming from the interaction between atmospheric gasses (nitrogen \& oxygen) and cosmic rays). Though $80 \%$ of radiation dose to the environment is from
Natural radionuclide while the remaining $20 \%$ is from cosmic rays and nuclear processes [1], the earth crust and the mantle remain the primary sources of materials that produce terrestrial natural occurring radioactive materials (NORMs). These materials may either be original (uranium \& thorium), they decay products or potassium. However, uranium and thorium decay series are the most important decay chains that provide radionuclides of concern in NORMs. The natural radio nuclides of concern in the terrestrial environment are mainly ${ }^{40} \mathrm{~K},{ }^{238} \mathrm{U}$ and ${ }^{232} \mathrm{Th}$ as well 
as the radioactive gas radon which is produced as these naturally occurring radioisotopes decay. ${ }^{226} \mathrm{Ra}$ a decay product of ${ }^{238} \mathrm{U}$ is wide spread in most rocks and soils and when it decays by alpha it produces ${ }^{222} \mathrm{Rn}$ which have a halflive of 3.8 days. ${ }^{222} \mathrm{Rn}$ has been found to emanate from the ground has as a result of the direct decay of naturally occurring radium and is a major source of radiation exposure [2]. Because of the short half-live of radon, the probability that its progeny will decay when breathed in air or dust is very high. The IARC monographs have concluded that there is adequate confirmation that radon-222 is a cause of lung cancer [3].

Tin as a mineral is form within the earth crust by a series of geological processes. Tin and tin alloy are widely used in the electronic industry for solder while its organic and inorganic compounds are used in plastic industries as well as in ceramics \& glaze respectively. Drilling, handling, storage, transportation of mineral ores as well as the use of polluted tools or waste media without controls usually lead to the spread of NORMs contaminating the environment and thus resulting in potential radiation exposure of members of the public [4]. The tin deposits in Barkin-ladi area of Plateau State are located within the clayey soil types derived from biotite-granites and biotite-hornblende-gneiss and weathered amphibolites [5]. Mining activities started in the area since 1904 and by the mid-1920s more cassiterite and columbite discoveries were made leading to a need for mechanized extraction methods. In 1930s commercial tin mining and processing started in Barkin-ladi attaining its peak production in $1950 \mathrm{~s}$ but it has been on the decline through the late seventies to present due to exhaustion of the high grades and easily worked out ores. Tin ore was mined in association with other ores such as columbite, wolfmite, thorite, zircon as well as monazites whose radioactive nature was obtained from their sources (biotite-granite) [6]. At each stage of tin ore processing, radioactive waste are generated, these tailings are not confined but rather dumped in heaps all over the environment. The heaps are within human habitation and are therefore used for various purposes ranging from moulding building blocks and in some cases for farming. Over time, mine tailings find their way during the raining season into nearby streams where sand are packed for building purposes and the water from the stream also used for irrigational purposes. The major problem is that the exposed natural radionuclides may gain access into man either by external irradiation (gamma ray), ingestion through intake of food and drinking water and inhalation of radon gas through air and dust particularly in poor ventilated houses (which is a major characteristic of the houses within the study area). Gamma radiation from natural radionuclides and cosmic rays constitute the external exposure to humans while those derived from inhalation and ingestion through the intake of foods and drinking water constitute internal exposure to humans. Health risk associated with the exposure to NORMs and breathing of short-lived decay products of radon are abundant; absorption of uranium through ingestion leads to the destruction of the kidney [7], Inhalation of radon decay products in poorly ventilated underground mines can lead to excess exposure to radiation and this could cause high incidence of lung cancer in mine workers [8] thus the need to study the radioactivity concentrations of radionuclides in these long abandoned tin tailings within the study area. Therefore, this study is aimed at measuring the concentrations of radionuclide in soil and sediment of abandoned tin mining sites in Barkin-ladi area so as to assess the associated lifetime cancer risk due to inhalation of the short life Radon gas.

Natural radioactivity is wide spread in the earth's environment, its distribution depends primarily on the geographical and geological conditions of the location and appears at different levels in the soils of each region worldwide. Barkin ladi is located on latitude $9^{0} 32^{\prime} 00$ ' $\mathrm{N}$ and longitude $8^{0} 54^{\prime} 00^{\prime \prime} \mathrm{E}$, it has a population of 175,265 based on the 2006 census. About $1200 \mathrm{~m}$ above the sea level, it is bounded by other mining villages including Marit /Mazat, Dorowa Babuje, Kuru Jenta and Bisichi. Barkin ladi has a mild cool climate condition with an annual mean temperature of $21.8^{\circ} \mathrm{c}$ receiving an average annual rainfall of about $1400 \mathrm{~mm}$, over $90 \%$ of rain falls between April and October [9]. According to [5], the area has a simple geology comprising of an ancient complex of Precambrian gneisses schist and granite of Jurassic. These younger granites are discordant, high level magmatic intrusions with strong alkaline affinities that cut the basement rocks. They are Jurassic in age and occur as ring structure with a common sequence of an early volcanic phase followed by series of granite intrusion and a crystalline basement consisting of undifferentiated magmatites are obtainable at its surrounding.

\section{Material and Methods}

\subsection{Sample Collections and Preparation}

Five samples were collected from fourteen locations making a total of forty two samples (21 ores and 21 sediments). The samples were collected using a spade and auger at a depth of $20 \mathrm{~cm}$ and a distance of $300 \mathrm{~cm}$ from each other. The sediments as well as the ores were oven dried at a temperature of $110^{\circ} \mathrm{c}$ for $24 \mathrm{hrs}$ to ensure that all available moisture was removed. Afterwards, the samples were crush into fine dust before sieving through a mesh having holes each of diameter $0.2 \mathrm{~mm}$ to remove all organic materials, piece of stones, gravel and lumps. Each sample was thoroughly mixed to ensure homogeneity and then weighed equally $(200 \mathrm{~g})$ and packed in a polyethylene beaker of height $7 \mathrm{~cm}$ and $6 \mathrm{~cm}$ diameter. The beakers were completely sealed for four (4) weeks to allow ${ }^{222} \mathrm{Rn}$ with half-life 3.8 days and its short-lived decay progenies of ${ }^{214} \mathrm{Bi}$ and ${ }^{214} \mathrm{~Pb}$ attain secular equilibrium with the long-lived ${ }^{226} \mathrm{Ra}$ predecessor in the samples.

\subsection{Gamma Spectrometry}

The prepared samples were analysed for natural occurring radionuclides using a $\mathrm{NaI}$ (Tl) scintillation 
detector. The gamma-ray spectroscopy set-up was coupled to a computer based Multichannel Analyzer (MCA) which was used for the data acquisition and analysis of gamma spectra. To trim down background radiation, the detector was enclosed in a $5 \mathrm{~cm}$ thick lead shield with a fixed bottom and a movable top cover. An empty beaker was first counted in the same manner and in the same geometry as the sample in other to determine the background distribution in the environment around the detector, the background spectra were used to correct the net photo peak of gamma rays of the measured isotopes by subtracting from the gross count. Each sample was counted for 3600s to reduce the statistical uncertainty. The energy and efficiency calibration of the gamma spectrometer was carried out using standard reference sources materials traceable to a mixed standard gamma source (ENV 94084-200g) by Analytic Inc., Atlanta, GA, USA. The detector assembly shows a resolution of $\sim 8 \%$ at $0.662 \mathrm{MeV}$ of ${ }^{137} \mathrm{Cs}$. The calculation of count rate for each detectable photo peak and radiological concentrations (activity per unit mass or specific activity) of detected radio nuclides depend on the establishment of secular equilibrium in the samples. The ${ }^{232} \mathrm{Th}$ concentration was determined from the $2614.5 \mathrm{keV}$ gamma-line of ${ }^{208} \mathrm{Tl}$ while $1764 \mathrm{keV}$ gamma- line of ${ }^{214} \mathrm{Bi}$ was used in the assessment of the activity concentration of ${ }^{226} \mathrm{Ra}$. The single line of $1460 \mathrm{keV}$ gamma-line of ${ }^{40} \mathrm{~K}$ was used to determine the concentration of ${ }^{40} \mathrm{~K}$ in the various samples. The specific activity $\left(\mathrm{A}_{\mathrm{c}}\right)$ measured in $\mathrm{Bqkg}^{-1}$ of the ores and sediments were determined using the net area under the photo peak and calculated according to equation (1) $[10]$.

$$
A_{s}=\frac{C_{n}}{\varepsilon_{\gamma} M_{S} \mathrm{I}_{\mathrm{\gamma}}}
$$

Where; $A_{\mathrm{s}}$ is the specific activity of radio nuclide in the sample specified in $\mathrm{Bqkg}^{-1}, C_{\mathrm{n}}$ is the net count per second of the sample under the corresponding photo peak, $\varepsilon_{\gamma}$ is the efficiency of the detector at the specific $\gamma$-ray energy of interest. $M_{\mathrm{s}}$ is the mass of the sample $(\mathrm{kg}) \mathrm{I}_{\gamma}$ is the intensity of gamma ray at the particular energy being counted.

\section{Results and Discussion}

\subsection{Specific Activity Concentration Calculation}

The average value of specific activity concentrations in ore and sediment samples from each location was obtained and listed in table 1 . The specific activity concentrations of ${ }^{40} \mathrm{~K}$ within the ore samples was found to be ranging from $93.3 \pm$ 29.8 to $666.8 \pm 93.3$ with an average of $275.44 \pm 46.14$, for ${ }^{226} \mathrm{Ra}$ was ranging from $81.1 \pm 22.2$ to $799.3 \pm 57.9$ with a mean value of $239.95 \pm 30.82$ while that of ${ }^{232} \mathrm{Th}$ was ranging from $171.1 \pm 11.4$ to $3604.0 \pm 68.4 \mathrm{Bqkg}^{-1}$ with an average of $778.78 \pm 29.30$. The concentrations of natural radioactivity within the sediments as obtained were ranging from $233.1 \pm$ 46.6 to $8536.8 \pm 31.1 \mathrm{Bqkg}^{-1}$ for ${ }^{40} \mathrm{~K}, 81.1 \pm 11.6$ to $2479.1 \pm$ $92.7 \mathrm{Bqkg}^{-1}$ for ${ }^{226} \mathrm{Ra}$ and $182.5 \pm 22.8$ to $26049 \pm 136.8$
$\mathrm{Bqkg}^{-1}$ for ${ }^{232} \mathrm{Th}$ respectively. Though specific activity of both the ores and sediments were generally high relative to the average recommended international activity values of 35 , 45 and $420 \mathrm{Bqkg}^{-1}$ for ${ }^{226} \mathrm{Ra},{ }^{232} \mathrm{Th},{ }^{40} \mathrm{~K}$ respectively, the activity of the sediments was found to be higher relative to ore samples contrary to the findings of Odumo et al. which report the activity of ore samples to be high compared to activity of sediment samples [11] but agreed with the National Nuclear Regulator report that there is an accumulation of radioactive nuclides in sediment of mine [12].

Table 1. Specific activity of radio nuclides in ores and sediments.

\begin{tabular}{llll}
\hline \multicolumn{4}{l}{ Activity concentration of radionuclides $\mathbf{B q K g}^{-1}$} \\
\hline Sample I.D & ${ }^{\mathbf{4 0}} \mathbf{K}$ & ${ }^{\mathbf{2 2}} \mathbf{R a}$ & ${ }^{\mathbf{2 3 2}} \mathbf{T h}$ \\
\hline Ore & Mean values & Mean values & Mean values \\
L-01 & $93.3 \pm 30.1$ & $81.1 \pm 22.2$ & $171.1 \pm 11.4$ \\
L-02 & $93.3 \pm 29.8$ & $92.7 \pm 22.7$ & $262.3 \pm 22.9$ \\
L-03 & $217.7 \pm 31.1$ & $104.2 \pm 23.1$ & $285.1 \pm 22.8$ \\
L-04 & $668.6 \pm 93.3$ & $799.3 \pm 57.9$ & $3604.0 \pm 68.4$ \\
L-05 & $435.4 \pm 46.6$ & $162.2 \pm 23.1$ & $353.5 \pm 22.6$ \\
L-06 & $217.7 \pm 46.5$ & $231.7 \pm 23.1$ & $342.1 \pm 22.8$ \\
L-07 & $202.1 \pm 45.6$ & $208.5 \pm 43.7$ & $433.4 \pm 34.2$ \\
Average & $275.44 \pm 46.14$ & $239.95 \pm 30.82$ & $778.78 \pm 29.30$ \\
Sediment & & & \\
L-08 & $513.1 \pm 46.6$ & $115.8 \pm 23.1$ & $262.3 \pm 22.8$ \\
L-09 & $8536.8 \pm 31.1$ & $2479.1 \pm 92.7$ & $26049.3 \pm 136.8$ \\
L-10 & $248.8 \pm 31.7$ & $81.1 \pm 11.6$ & $342.1 \pm 22.8$ \\
L-11 & $233.1 \pm 46.6$ & $173.8 \pm 23.1$ & $399.2 \pm 21.9$ \\
L-12 & $435.5 \pm 46.6$ & $173.8 \pm 23.1$ & $182.5 \pm 22.8$ \\
L-13 & $388.7 \pm 62.2$ & $312.8 \pm 23.1$ & $1243.1 \pm 22.8$ \\
L-14 & $901.9 \pm 124.4$ & $1981.0 \pm 139.0$ & $5554.3 \pm 91.2$ \\
Average & $1608.25 \pm 55.60$ & $759.62 \pm 47.95$ & $4861.82 \pm 48.72$ \\
\hline
\end{tabular}

Table 2a. Absorbed dose rate, Radium equivalent, Annual effective dose and Excess life cancer risk in ore samples.

\begin{tabular}{llllll}
\hline $\begin{array}{l}\text { Sample } \\
\text { ID }\end{array}$ & D $\left(\mathbf{n G y h}^{-\mathbf{1}}\right)$ & $\begin{array}{l}\mathbf{R a}_{\text {eq }} \\
\left.\mathbf{( B q k g}^{-1}\right)\end{array}$ & $\begin{array}{l}\text { AOEDR } \\
\left(\mathbf{m S v y}^{-1}\right)\end{array}$ & $\begin{array}{l}\text { AIEDR } \\
\left(\mathbf{m S v y}^{1}\right)\end{array}$ & ELCR \\
\hline L-01 & 151.90 & 332.97 & 0.19 & 0.76 & 0.0026 \\
L-02 & 217.24 & 474.97 & 0.28 & 1.07 & 0.0037 \\
L-03 & 242.59 & 528.66 & 0.29 & 1.19 & 0.0042 \\
L-04 & 2755.89 & 6004.50 & 3.38 & 13.51 & 0.0473 \\
L-05 & 321.99 & 701.23 & 0.39 & 1.58 & 0.0055 \\
L-06 & 33.77 & 737.66 & 0.41 & 1.64 & 0.0058 \\
L-07 & 384.63 & 843.82 & 0.47 & 1.89 & 0.0066 \\
Average & 629.86 & 1374.83 & 0.77 & 3.09 & 0.0107 \\
\hline
\end{tabular}

Table 2b. Absorbed dose rate, Radium equivalent, Annual effective dose and Excess life cancer risk in sediment samples.

\begin{tabular}{llllll}
\hline $\begin{array}{l}\text { Sample } \\
\text { ID }\end{array}$ & $\begin{array}{l}\text { Dose rate } \\
\left.\mathbf{( n G y h}^{-1}\right)\end{array}$ & $\begin{array}{l}\mathbf{R a}_{\text {eq }} \\
\left.\mathbf{( B q k g}^{-1}\right)\end{array}$ & $\begin{array}{l}\text { AOEDR } \\
\left(\mathbf{m S v y}^{-1}\right)\end{array}$ & $\begin{array}{l}\text { AIEDR } \\
\left(\mathbf{m S v y}^{-1}\right)\end{array}$ & ELCR \\
\hline L-08 & 245.15 & 530.39 & 0.30 & 1.20 & 0.0042 \\
L-09 & 18670.29 & 40386.93 & 22.89 & 91.59 & 0.3205 \\
L-10 & 271.79 & 589.46 & 0.33 & 1.33 & 0.0046 \\
L-11 & 348.51 & 762.61 & 0.43 & 1.71 & 0.0059 \\
L-12 & 213.75 & 468.30 & 0.26 & 1.05 & 0.0036 \\
L-13 & 973.21 & 2120.36 & 1.19 & 4.77 & 0.0167 \\
L-14 & 4561.615 & 99993.09 & 5.59 & 22.37 & 0.078 \\
Average & 3612.047 & 7835.879 & 4.43 & 17.72 & 0.0620 \\
\hline
\end{tabular}




\subsection{Absorbed Dose Rate}

For the purpose of assessing the radiation hazards due to the concentrations of natural occurring radionuclides ${ }^{226} \mathrm{Ra}$, ${ }^{232} \mathrm{Th}$ and ${ }^{40} \mathrm{~K}$ in the samples, the absorbed dose in air at $1 \mathrm{~m}$ above the ores and the sediments were calculated using equation (2) according to the guidelines provided by [13].

$$
\mathrm{D}=\left[0.427 \mathrm{~A}_{\mathrm{Ra}}+0.662 \mathrm{~A}_{\mathrm{Th}}+0.043 \mathrm{~A}_{\mathrm{K}}\right] \mathrm{nGyh}^{-1}
$$

Where: $\mathrm{D}$ is the absorbed dose rate in air $1 \mathrm{~m}$ above the ground. $A_{R a}, A_{T h}$ and $A_{k}$ are the specific activity concentrations of ${ }^{226} \mathrm{Ra},{ }^{232} \mathrm{Th}$ and ${ }^{40} \mathrm{~K}$ measured in $\mathrm{Bqkg}^{-1}$. While $0.043 \mathrm{nGyh}^{-1} / \mathrm{Bqkg}^{-1}, \quad 0.662 \mathrm{nGyh}^{-1} / \mathrm{Bqkg}^{-1}$ and $0.427 \mathrm{nGyh}^{-1} / \mathrm{Bqkg}^{-1}$ are the conversion factor for ${ }^{40} \mathrm{~K},{ }^{232} \mathrm{Th}$ and ${ }^{226} \mathrm{Ra}$ respectively.

The results obtain were presented in table $2 \mathrm{a}$ for ores and table $2 \mathrm{~b}$ for sediments respectively. The absorbed dose varies from $33.77-2755.89 \mathrm{nGyh}^{-1}$ in ore samples (Table 2a) and from 213 - $18670.29 \mathrm{nGyh}^{-1}$ in sediment samples (table 2b). Though the study show the mean absorbed dose in ore samples $\left(629.86 \mathrm{nGyh}^{-1}\right)$ to be lower than the mean absorbed dose in sediment samples (3612.05 $\mathrm{nGyh}^{-1}$ ) both values are higher than the global average values ranging from $10-200 \mathrm{nGyh}^{-1}$ [16], these findings agreed with the report of [10] which reported a mean absorbed dose above world average values from tin mining dumpsites in, JosPlateau.

\subsection{Radium Equivalent Activity}

Owing to the variation in the distribution of ${ }^{226} \mathrm{Ra},{ }^{232} \mathrm{Th}$ and ${ }^{40} \mathrm{~K}$ inside the soil, the radium equivalent concentration $\left(\mathrm{Ra}_{\mathrm{eq}}\right)$ calculated based on equation (3) [14] can be used as a common index to compare the specific activities of samples containing ${ }^{226} \mathrm{Ra},{ }^{232} \mathrm{Th}$ and ${ }^{40} \mathrm{~K}$ in varying concentrations.

$$
\mathrm{Ra}_{\mathrm{eq}}=\left[\mathrm{A}_{\mathrm{Ra}}+1.43 \mathrm{~A}_{\mathrm{Th}}+0.077 \mathrm{~A}_{\mathrm{K}}\right] \mathrm{Bqkg}^{-1}
$$

Where: $A_{\text {Ra }}, A_{T h}$ and $A_{K}$ are the specific activity concentration in $\mathrm{Bqkg}^{-1}$ of ${ }^{226} \mathrm{Ra},{ }^{232} \mathrm{Th}$ and ${ }^{40} \mathrm{~K}$ respectively.

The maximum value of $\mathrm{Ra}_{\mathrm{eq}}$ within the ore samples was observed to be $6004.50 \mathrm{Bqkg}^{-1}$ in sample I.D 4 while the minimum was $332.97 \mathrm{Bqkg}^{-1}$ in sample I.D 1 (table 2a). The minimum and maximum values of $\mathrm{Ra}_{\mathrm{eq}}$ within the sediment samples were 468.30 and $9993.09 \mathrm{Bqkg}^{-1}$ in sample I.D 12 and I.D 14 respectively (table 2b). Radium equivalent concentration was calculated based on the estimation that 370 $\mathrm{Bqkg}^{-1}$ of ${ }^{226} \mathrm{Ra}, 259 \mathrm{Bqkg}^{-1}$ of ${ }^{232} \mathrm{Th}^{2}$ and $370 \mathrm{Bqkg}^{-1}$ of ${ }^{40} \mathrm{~K}$ produce the same gamma-ray dose rate of radiation [15]. However, for safety purpose, the maximum values of $\mathrm{Ra}_{\mathrm{eq}}$ must be below $370 \mathrm{Bqkg}^{-1}$ which is comparable to the annual dose equivalent of $1 \mathrm{mSv} / \mathrm{y}$ that is globally accepted to be the maximum permissible dose to members of the general public from their exposure to natural radiation from soil within one year as specified by [9].

\subsection{Annual Effective Dose Rate (AEDR)}

The estimated effective dose equivalent received annually by a member is calculated using the conversation factor of $0.7 \mathrm{SvGy}^{-1}$ which is used to convert the absorbed dose rate to human effective dose equivalent by means of an outdoor occupancy factor of $20 \%$ and an indoor occupancy factor of $80 \%$ [16]. The annual effective dose was estimated by converting the gamma absorbed doses in $\mathrm{nGyh}^{-1}$ to annual effective dose in $\mathrm{mSvy}^{-1}$ as proposed by [8] using equation (4).

$$
\mathrm{AIEDR}=\left[\mathrm{A}_{\mathrm{DR}} \times \mathrm{T} \times \mathrm{D}_{\mathrm{CF}} \times \mathrm{F}_{\mathrm{IC}} \times 10^{-6}\right] \mathrm{mSvy}^{-1}
$$

Where, AIEDR is the annual indoor effective dose rate, $\mathrm{A}_{\mathrm{DR}}\left(\mathrm{nGy}^{-1}\right)$ is the absorbed dose rate, $\mathrm{T}$ is the hours of the year $\left(8760 \mathrm{hy}^{-1}\right), \mathrm{D}_{\mathrm{CF}}$ is the dose conversion factor $\left(0.7 \mathrm{SvGy}^{-}\right.$ $\left.{ }^{1}\right), F_{I C}$ is the indoor occupancy factor $(0.8)$ and $10^{-6}$ is the factor converting nano to milli.

The results obtained and presented in table $2 \mathrm{a}$ for ore samples shows that, the values of annual indoor absorbed dose rate ranging from $0.76-13.51 \mathrm{mSvy}^{-1}$ with a mean value of $3.09 \mathrm{mSvy}^{-1}$. Table $2 \mathrm{~b}$ shows the values of annual indoor absorbed dose rate within the sediments samples ranging from $1.05-91.59 \mathrm{mSvy}^{-1}$ with an average 17.72 $\mathrm{mSvy}^{-1}$. However, these values in ores and sediments in this present study are higher than the global average indoor terrestrial radiation value of $0.50 \mathrm{mSvy}^{-1}$ recommended by [8].

\subsection{Excess Lifetime Cancer Risk (ELCR)}

Radium-266 is a decay product of uranium-238, when ${ }^{226} \mathrm{Ra}$ undergoes alpha decay ${ }^{222} \mathrm{Rn}$ is produced. Radium-226 is primarily deposited in bone whereas radon-222 is deposited in the lungs upon inhalation. The accumulation of these radio nuclides over a long period of time could increase ones risk of cancer. Excess life time cancer risk was calculated using equation (5) [17]

$$
\mathrm{ELCR}=\mathrm{AIEDR} \times \mathrm{D}_{\mathrm{LF}} \times \mathrm{R}_{\mathrm{FT}} \times 10^{-3}
$$

Where AIEDR is the annual indoor effective dose rate measured in $\mathrm{mSvy}^{-1}, \mathrm{D}_{\mathrm{LF}}$ is the duration of life (70 years) and $\mathrm{R}_{\mathrm{FT}}$ is the risk factor $\left(\mathrm{Sv}^{-1}\right)$ fatal cancer risk per Sievert and for stochastic effects, [13] uses the value of 0.05 for the general public.

The excess lifetime cancer risk of ore and sediments are presented in table $2 \mathrm{a}$ and table $2 \mathrm{~b}$ respectively. The calculated values of excess life time cancer risk for ores samples ranges from 0.0026 (sample ID L-1) to 0.0473 (sample ID L-4) with an average of 0.0107 (table 2a). The ELCR values value for sediments samples was found to range from 0.0036 (sample ID L-12) to 0.3205 (sample ID L9) with an average of 0.062 . Although the excess lifetime cancer risk values in this present study were higher in sediment samples relative to ore samples, the excess lifetime cancer risk (ELCR) values within the study area were generally high compare to the global average value of 0.00027 given by [13] as the safety limit. However, the cancer rate of the inhabitants within the study area was not evaluated because reliable standardised mortality and 
morbidity statistics were not accessible, this research was restricted to background radiation levels from tin ores and sediments and only the indoor occupancy factor was considered in assessing the cancer risk because people spend more time indoor than outdoor and in case of outdoor occupancy, the radon gas is easily diluted even in high background radiation areas.

\section{Conclusion}

The radionuclide contents, specific activity concentrations and radiological impact of tin ore and sediments from Barkin-Ladi area were investigated in the present study with an aim of assessing the excess lifetime cancer risk owing to the exposure of the populace to these radionuclides. The average radioactivity levels of natural occurring radionuclides ${ }^{40} \mathrm{~K},{ }^{226} \mathrm{Ra}$ and ${ }^{232} \mathrm{Th}$ in the collected ores samples were $275.44 \pm 46.14,239.95 \pm 30.82$ and $778.78 \pm$ $29.30 \mathrm{Bqkg}^{-1}$ respectively while those of the sediment samples were $1608.25 \pm 55.60,759.62 \pm 47.95$ and 4861.82 $\pm 48.78 \mathrm{Bqkg}^{-1}$. The mean radioactivity concentration of ${ }^{40} \mathrm{~K}$ was lower than the world average in ore samples. But the average radioactivity concentrations of ${ }^{226} \mathrm{Ra}$ and ${ }^{232} \mathrm{Th}$ were significantly higher than that of the world average permissible limits. The average radioactivity concentrations of ${ }^{40} \mathrm{~K},{ }^{226} \mathrm{Ra}$ and ${ }^{232} \mathrm{Th}$ in the sediment samples were significantly higher than the world average values. Although variation was observed in radioactivity concentrations with different locations in both the ore and sediment samples, radioactivity concentrations were generally found to be higher in sediment samples than in ore samples. The calculated absorbed dose, radium equivalent activity and annual effective dose rate in the ore and sediments samples were also found to be above the world average values. Therefore, the area under present study might be termed as a high background radiation area and radiologically unsafe. The excess lifetime cancer risk (ELCR) values in the investigated tin ore samples owing to the specific activity of ${ }^{40} \mathrm{~K},{ }^{226} \mathrm{Ra}$ and ${ }^{232} \mathrm{Th}$ are above the acceptable limit 0.00027. Therefore, there is need for the population living in close proximity to the abandoned tin mining sites to take precaution by ensuring they live in well ventilated houses since exposure to radiation at any level is known to be harmful to life.

\section{References}

[1] International Atomic Energy Agency (IAEA, 1996): Radiation safety, Regulation for the safe transport of radioactive material IAEA Division of public information, 96-00725 IAEA/PI/A47E.

[2] Environmental Protection Agency, (EPA, 2007): United States. Ionizing radiation fact book, EPA. Office of radiation and indoor air. EPA-402-F-06-061.
[3] International Agency for Research on Cancer (IARC, 2012): A review of human carcinogens; radiation. IARC monographs on the evaluation of carcinogenic risks to human, Vol. $100 \mathrm{D}$.

[4] Innocent, A. J., Onimisi, M. Y., \& Jonah, S.A. (2013): Evaluation of naturally occurring radionuclide materials in soil sample collected from some mining sites in Zamfara State, Nigeria. British Journal of applied Science \& Technology, 3(4), 684-692.

[5] Buchaman, M.S., Macleod, W.N. and Turner, D.C. (1971). The geology of Jos Plateau. Bulletin Geology survey of Nigeria, 2(32)

[6] Onuoha, K.M. (1992). The boom and burst in Nigeria's solid mineral subsector. Tin and columbite case histories. Journal of mining and geology 28(2), 353-357.

[7] Hush, J.B., Spoor, N.I.,(1973): Data on man. In: Hodge, H.C., et al. (Eds), Hand book of experimental pharmacology. Uranium, Platonium, Plutonium, Transplutonic elements springer-verlag, Berlin. 36, 197-240.

[8] United Nation Scientific Committee on the Effects of Atomic Radiation (UNSCEAR, 2000): Radiation sources and effects of ionizing radiation, New York, USA: United Nations, Report of the United Nations Scientific Committee on the Effect of Atomic Radiation to the General Assembly.

[9] Udo, R.K (1970): Geological regions of Nigeria. Published by Hemisphere Publishing Corporation.

[10] Masok, F.B., Masiteng, P.L., \& Jwanbot, I. D (2015). Natural radioactivity concentrationand effective dose rate from tin mining dumpsites in Rayfield, Nigeria. Journal of environment and earth science 5(12), 51-55.

[11] Odumo, O.B., Mustapha, A.O., Patel, J.P \& Angeyo H.K (2011): Radiological survey and assessment of associated activity concentration of the naturally occurring radioactive materials in Migori artisanal gold mining belt of Southern Nyanza, Kenya. Applied Radiation and isotopes (69) 912-916.

[12] National Nuclear Regulator, (2007). Radiological Imapact of the mining activities to the public in the Wonderfontein catchment area. Repot No. TR-RRD-07-2006.

[13] International Commission on Radiological Protection (ICRP90, 1991): Recommendations of the International Commission on radiological Protection. Annals of the ICRP, 21, 1-3.

[14] United Nation Scientific Committee on the Effects of Atomic Radiation (UNSCEAR, 1982). Ionizing radiation; Sources and biological effects. Report of General Assembly, with Annexes, United Nation, New York

[15] Yu, K. N., \& Gau, Z. J., Stoks, M.J., \& Young, E.C. (1992): Assessment of natural radiation dose committed to the Hong Kong people. Journal of Radioactivity, 17, 931

[16] United Nation Scientific Committee on the Effects of Atomic Radiation (UNSCEAR, 1993). Radiation Exposure from natural sources of radiation. New York; United Nation.

[17] Taskin, H., Karavus, M., Ay, P., Topuzoglu, A., Hindiroglu, S., \& Karahan,G. (2009): Radilonuclides concentrations in soil and lifetime cancer risk due to the gamma radilactivity in Kirklareli, Turkey. Journal of Environmental Radioactivity, (100) 49-53. 